\title{
The contracting world of girls at puberty: Violence and gender- divergent access to the public sphere among adolescents in South Africa
}

Kelly Hallman

Population Council

Nora Kenworthy

Judith A. Diers

Nick Swan

Bashi Devnarain

Follow this and additional works at: https://knowledgecommons.popcouncil.org/departments_sbsr-pgy

Part of the Demography, Population, and Ecology Commons, Domestic and Intimate Partner Violence Commons, Family, Life Course, and Society Commons, Gender and Sexuality Commons, Gender Equity in Education Commons, International Public Health Commons, Maternal and Child Health Commons, and the Women's Health Commons How does access to this work benefit you? Let us know!

\section{Recommended Citation}

Hallman, Kelly, Nora Kenworthy, Judith A. Diers, Nick Swan, and Bashi Devnarain. 2013. "The contracting world of girls at puberty: Violence and gender-divergent access to the public sphere among adolescents in South Africa," Poverty, Gender, and Youth Working Paper no. 25. New York: Population Council. Version of record: https://doi.org/10.1080/17441692.2014.964746 


\section{THE CONTRACTING WORLD OF GIRLS}

AT PUBERTY: VIOLENCE AND

GENDER-DIVERGENT ACCESS TO

THE PUBLIC SPHERE AMONG

ADOLESCENTS IN SOUTH AFRICA

Kelly K. Hallman, Nora J. Kenworthy, Judith Diers, Nick Swan, and Bashi Devnarain 


\section{(2) Population Council}

One Dag Hammarskjold Plaza

New York, New York 10017 USA

www.popcouncil.org

The Population Council confronts critical health and development issues-from stopping the spread of HIV to improving reproductive health and ensuring that young people lead full and productive lives. Through biomedical, social science, and public health research in 50 countries, we work with our partners to deliver solutions that lead to more effective policies, programs, and technologies that improve lives around the world. Established in 1952 and headquartered in New York, the Council is a nongovernmental, nonprofit organization governed by an international board of trustees.

For information on Poverty, Gender, and Youth working papers, see

www.popcouncil.org/publications/wp.asp

This material may not be reproduced without written permission from the Population Council.

ISSN: $1554-8538$

(c) 2013 The Population Council, Inc. 


\title{
The Contracting World of Girls at Puberty: Violence and Gender-Divergent Access to the Public Sphere among Adolescents in South Africa
}

\author{
Kelly K. Hallman \\ Nora J. Kenworthy \\ Judith Diers \\ Nick Swan \\ Bashi Devnarain
}

Kelly K. Hallman is Senior Associate, Poverty, Gender, and Youth program, Population Council, New York. Nora J. Kenworthy is Assistant Professor, Nursing and Health Studies Program, University of Washington, Bothell. Judith Diers is Chief, Adolescent Development and Participation Section, UNICEF, New York. Nick Swan is Director, Isithunzi Development, eThekwini, South Africa. Bashi Devnarain is Director, Crime Reduction in Schools Project (CRISP) Trust, eThekwini, South Africa.

This working paper is based on a collaborative project undertaken by the Crime Reduction in Schools Project (CRISP Trust), UNICEF, the KwaZulu-Natal Department of Education, and the Population Council. We acknowledge Nonkululeko Mthembu for leading the mapping fieldwork; Judith Bruce for her tireless efforts to inform policymakers of the need for safe social spaces for girls; Cynthia B. Lloyd for her support in identifying this endeavor as a potential project; Sibeso Luswata, Andrea Berther, Gerrit Maritz, and Misrak Elias for guidance during the project; Robert Heidel, Sura Rosenthal, Hannah Taboada, Mike Vosika, Christina Tse, and Kirk Deitsch for suggestions on the text and graphics; and Wendy Baldwin, four anonymous referees, and participants in the July 22-24, 2013 UNFPA-Population Council Adolescent Programming Workshop in New York for helpful comments.

Financial support was provided by UNICEF, the UK Department for International Development (DfID) through the Addressing the Balance of Burden in AIDS Research Programme Consortium (ABBA RPC), a Hewlett Foundation grant to the Population Council, the Gates Foundation, and the National Institutes of Health, Doctoral Research Training Grant in Gender, Sexuality and Health, Grant Number 5 T32 HD049339-02 NIH/NICHD. 


\begin{abstract}
Participatory mapping was undertaken with single-sex groups of grade 5 and grade 8-9 children in urban and rural KwaZulu-Natal, South Africa. Wide gender divergence in access to the public sphere was found among grade 8-9 children. At grade 5, female self-defined community areas were equal to or larger in size than those of males in both sites. Community area depicted by urban grade 8-9 girls, however, was only 34 percent that of classmate boys and 41 percent that of grade 5 girls. Conversely, community area defined by grade 8-9 boys was 206 percent that of grade 5 boys. Similar differences emerged in the rural site. No female group rated a single space as more than "somewhat safe." Although curtailed spatial access, especially in urban areas, is intended to protect post-pubescent girls, grade 8-9 girls reported most spaces in their small navigable area as unsafe. The large geographies of grade 8-9 males contained a wide mix of safe and unsafe places. Reducing girls' access to the public sphere does not increase their perceived safety, but may instead limit their access to opportunities for human development.
\end{abstract}


As new generations come of age under democracy, adolescents in post-apartheid South Africa ostensibly face bright new prospects. Nevertheless, many of their daily activities are overshadowed by social, economic, and physical risks that limit their access to the public sphere and hence to opportunities. In addition to facing threats from HIV and AIDS, systemic structural inequality, and high rates of unemployment, young women and men account for a large proportion of the victims of widespread violence and crime. Although the incidence of political violence has declined since the democratic transition, South Africa experiences high rates of violent and property crimes as well as domestic abuse and abuse by sexual partners (Jewkes 2013; Jewkes et al. 2010; Seedat et al. 2009; Jewkes et al. 2009; Naude, Prinsloo, and Ladikos 2006). Public protection from such forms of violence remains inadequate, leaving the population to attempt to bolster their security at great personal cost. For those with neither the financial nor the social capital for such defenses, violence creates a frightening reality that most heavily affects those who already have the fewest social protections: adolescents. This group lacks the social safeguards provided to young children as well as the legal and civic rights accessible to adults.

Worldwide, adolescence is the age of highest risk for intentional injury (Lozano et al. 2013). According to South Africa's National Injury Mortality Surveillance System, the leading cause of death among 10-19-year-olds in 2008 (the most recent year available) was violence (36 percent), followed by transport accidents (30 percent), non-transport accidents (15 percent), and suicide (13 percent), with the remaining causes undetermined (6 percent) (MRC-UNISA 2010). Adolescent concerns about the threat of violence are real and borne out by such statistics. Despite the prevalence of violence and the widespread media attention devoted to it, however, the relationship between violence in the community and adolescent access to the public sphere has not been systematically examined in South Africa.

In the United States, neighborhood violence has been linked to earlier sexual initiation (Choby et al. 2012; Kim 2010; Upchurch et al. 1999; Aneshensel and Sucoff 1996), poorer adolescent mental health (Dupéré et al. 2012; Zona and Milan 2011; Shields et al. 2010), higher rates of obesity (Whitaker 2010), and a reduced ability - especially of girls - to conduct basic activities of daily life: to venture outside the home, safely attend and return from school, stay after school, play, or participate in training programs (Bennett et al. 2007; Davison and Jago 2009; Gomez et al. 2004; Kimm et al. 2002). Parents in poor, disorganized neighborhoods tend to exert more control over adolescents than parents in better-off, safer neighborhoods in an attempt to protect their children from harm, and girls are much more tightly regulated than boys (Galambos et al. 2009; Hilbrecht et al. 2008). Attempts to increase girls' safety include requiring them to stay close to home, limiting their movements in the community, and playing only in "safe" places, if and when these exist. Geographic locations characterized by social disarray, coupled with slim economic prospects, can create environments where crime and fear lead to social isolation. This state of affairs often becomes normalized, thus continuing a cycle that is socially, physically, and psychologically unhealthy.

There is little evidence from low- and middle-income countries on how chronic crime and interpersonal violence create the sorts of unsafe conditions that "infiltrate the everyday and the 
ordinary" (Das 2007). In particular, it is unclear how perceptions of violence influence and possibly limit the choices and capabilities of adolescents by sex, age, and community type.

The South African Police Service (SAPS) Annual Report 2011/2012 includes statistics on crimes committed against children. While 0-17-year-olds comprise 35 percent of the national population, this group constituted 7 percent of murder or attempted murder victims, 8 percent of non-sexual assault victims, and 38 percent of sexual offense victims. Crimes reported against children disaggregated by victim year of age are shown in Figure 1 for adolescents. Victimization of all types rises with age. Both sexual offenses and non-sexual assault increase rapidly after age 10 , with reported sexual offenses among this age group peaking at ages 14-15. While the SAPS data for child victims are unfortunately not disaggregated by sex, national crime statistics for adults indicate that women represent 16 percent of murder/attempted murder victims, 39 percent of non-sexual assault victims, and 81 percent of sexual offense victims.

Despite this evidence, there is virtually no information on how adolescents themselves perceive violence by age and sex. Given the rapid social, physical, emotional, and sexual changes that occur during this life stage, we hypothesize that variations by age and sex are likely. That such maturation occurs earlier for girls than boys (and perhaps earlier than for previous generations of girls) lends a further possible age-sex dimension to the question. Finally, the vast majority of research on neighborhood violence and its implications for young people's access to the community focuses on urban neighborhoods; in most countries, data on youth injury or experience of crime are not reported by urban-rural residence (Singh et al. 2012). While rates of violent crime are generally lower in rural areas because of lower population density, there is no reason to assume that perceptions of threat are absent for rural adolescents.

\section{BACKGROUND: ADOLESCENT GEOGRAPHIES}

Adolescent geographies can be conceptualized as overlapping "action spaces" through which boys and girls move in their daily lives, exposing them to differing levels of social opportunity and risk. Cummins et al. (2007) articulated relational theories that motivate this analysis, in particular Actor Network Theory as described by Latour (1996) and Murdoch (1998). This theory hypothesizes that activities are organized within geographic spaces characterized not only by physical distance but also by the relational proximity and social distance of people of different ranks and hierarchies. This social distance continues to strongly permeate daily life and social relationships in South Africa.

The 2005 South African National Youth Victimization Survey revealed that adolescents faced high rates of violence, with more than 40 percent having been the victim of a crime in the previous year (Leoschut and Burton 2006). The bulk of homicides and violent injuries in South Africa are borne by young males, while young females experience exceptionally high rates of rape and sexual assault (Townsend et al. 2011; Jewkes et al. 2010; Seedat et al. 2009). These circumstances are strongly reinforced by gender hierarchies, socially pervasive forms of masculinity, and exploitative power dynamics within social institutions (Seedat et al. 2009; Moffett 2006; Morrell 1998). Further, the vast majority of perpetrators of crimes committed against and witnessed by adolescents are individuals who reside in the community and are personally known by the adolescent (Jewkes and Abrahams 2002). Often, these perpetrators are 
the very persons charged with protecting children and adolescents: neighbors, educators, and family members (Leoschut and Burton 2006). Thus, adolescents' safety is eroded in familiar private and public spaces by persons whom they should in theory be able to trust.

With the release of a Human Rights Watch (2001) report on sexual violence against girls in South African schools, school-based sexual violence became a topic of research in low- and middle-income countries. Subsequent studies often focused on girls as victims and boys and/or teachers as perpetrators, with singular concerns about HIV infection, ignoring more widespread patterns and consequences of violence outside of school (e.g., Mirsky 2003; Leach and Humphreys 2007). Much of this research, with the important exceptions of CIET Africa (2000), Jewkes et al. (2002), Brooks and Higson-Smith (2004), and Richter et al. (2004), failed to explore wider patterns of community-level or inter-relational violence from the perspective of adolescents. The mapping study we describe below seeks to identify variations and deficits in the geographies of safety from adolescents' perspectives and within the context of their different stages of development.

\section{Methods: PARTICIPATORY MAPPING}

Published research on adolescents and violence in low- and middle-income countries has consisted primarily of police victimization reports, cause-of-death studies, or non-fatal injury surveys. While these are obviously crucial quantitative measures, they fail to lend voice to adolescent perceptions of their community and to locate such perceptions within street-by-street (or field-by-field) geographies. Knowledge of children's perceptions and beliefs about safety is essential, given that much of the violence experienced by young people is often hidden and largely unreported (Pinheiro 2006). Participatory mapping has been used widely since the 1960s by anthropologists and international development researchers seeking to involve socially or economically marginalized groups in identifying local problems, often with the goal of informing policy decisions or mobilizing grassroots action (Chambers 1992, 1994; Mukherjee 1993; Creswell, 1998). With increasing attention in international health research to adolescent girls, participatory mapping has been used to gain an understanding of places in the community that are accessible to girls. Following work by Stromquist (1996) on the social cartography of gendered spaces and by Mitchell and colleagues (1998) on feminist mapping, a variety of girl empowerment initiatives and research projects have used the method, often as a way for researchers to interact with girls and their guardians upon first entering a community. Seldom, however, are the findings from such exercises submitted for peer review, frequently because only a single demographic group (girls within a particular age range) is involved and thus comparative analysis is not possible. Noteworthy exceptions include Lary et al.'s (2004) study of single-sex groups of 16-24-year-olds in Dar es Salaam; Mitchell et al.'s (2005) gender-disaggregated study of 12-13-year-old school children in Swaziland; Power et al.'s (2007) research on single-sex groups of grade 9-11 students in Zimbabwe; and Winton's (2005) research in Guatemala with mixed-sex groups of young women and men aged 9 to 23. These studies made enlightening sexspecific observations, but none of the research designs permitted analysis of sex-specific findings by age, school grade, or human development stage. As far as we know, ours is the only study that 
examines sex, grade level, and urban-rural aspects of community safety and violence as perceived and mapped by adolescents.

Participatory mapping provides a detailed portrait of perceived local spaces. In this regard it can identify and aid in creating safe spaces for adolescents. As a visual methodology, participant mapping is accessible and politically salient, able to clearly express and portray to policymakers the views of a population that is often unheard. As a method of consciousnessraising, it allows adolescents to identify and reflect on their experiences while developing concrete ideas for community improvement (Mitchell 2011).

\section{The KwaZulu-Natal STudy}

To explore the relationship between perceived violence and adolescent access to the public sphere by sex, grade, and urban-rural residence, the Population Council collaborated in 2004-05 with the Crime Reduction in Schools Project (CRISP) Trust, UNICEF, and the KwaZulu-Natal Department of Education to conduct participatory exercises with school children in urban and rural communities in KwaZulu-Natal Province, South Africa. The study was conducted in two low-resource areas in the province in which CRISP Trust was active at the time: an urban township and a rural community. Students in one primary and one secondary school in each area participated in the study, resulting in four groups per community: grade 5 girls, grade 5 boys, grade $8-9$ girls, and grade $8-9$ boys. There was an average of 17 students per group (range: $\mathrm{n}=13-22$ ). The mean age for grade 5 students was 11 years (range 9-13 years); the mean age for grade 8-9 students was 14.5 years (range 13-17 years). Grade 5 and grades 8-9 were chosen to compare the perceptions of adolescents at two different stages of development: pre-adolescence and early-to-mid-adolescence. Comparing students at these grade levels is also salient because South African grade 5 children attend upper primary school, and grade 8-9 children are in the early stage of secondary school, and are thus exposed to different school environments and peers, as well as different distances and commutes to school.

With the guidance of trained young adult Zulu- and English-speaking bilingual facilitators, each group was given a blank piece of paper four by five feet, colored markers, colored construction paper, and tape. They were asked to draw the area that represented their community and to indicate places in the community and rate each in terms of its safety or lack of safety, using the following categories: extremely safe, very safe, somewhat safe, sometimes safe/sometimes unsafe, somewhat unsafe, very unsafe, or extremely unsafe. The research team did not define criteria for the various categories of safety; the groups were allowed to determine these themselves in the course of their discussion. Groups also developed their own symbols for depicting various places on their maps.

Ethical procedures were followed in the research, including informed consent from school principals and from teachers and guardians of children in participating classrooms, as well as informed assent of all child participants (aged 9-17 years) and informed consent from independent minors. CRISP Trust retained all informed consent documents in locked file cabinets in their offices in Durban. A social worker and/or school guidance counselor was present during each group session. Individual participant names were not collected during the research, so the risk of linking information collected with any individual is very low. School, road, 
landmark and community names were removed from any materials disseminated outside the immediate study neighborhood.

With maps drawn freehand and the place symbols defined differently by each participant group, direct comparison of the maps proved difficult. The contents of each map were therefore analyzed by the research team by matching all features depicted on that map with those appearing on Google satellite images for each locality. Given this variation in the raw maps and to maintain the anonymity of the communities and schools where the research occurred, neither the raw maps nor the matched, place-labeled Google satellite images are presented here. (The raw participant maps devoid of place names are available from the first author.) Instead, the boundaries of the physical area depicted by each participant group, determined by plotting mapped features on Google satellite images, are presented on unlabeled Google satellite images of each study site. Using the perimeters of each group's mapped area, the relative sizes of different groups' physical "community" were assessed (www.draftlogic.com Google maps area calculator was used to determine area). In addition, to compare varying perceptions of spaces within the same community, we contrast the sex-age safety ratings of places plotted by the four groups in each site.

CRISP Trust presented the results of this exercise to local authorities in each study community as a means to provide information about sex- and age-specific perceptions of safe and unsafe places. Meetings were held with school principals, educators, school boards, and inter-sectoral community development forums to bring attention to the adolescents' findings and discuss proposed next steps.

\section{Findings: DePictions of Community ANd SAFE ANd UnSAFE SPACES}

Figures 2-7 present the spatial area defined as "community" by each sex, grade, and locality group. Figure 2 shows the geographic areas plotted by grade 5 and grade $8-9$ urban girls. The size of the area mapped by the younger girls, 6.33 square miles, was substantially greater than that shown by older girls, 2.62 square miles. This disparity represents a greatly contracted area of access to the public sphere with age: younger girls' area is 2.5 times larger than that of older girls. In Figure 3, on the other hand, boundaries of this same community as defined by urban boys reveal growing male spatial access with age. The area represented by younger boys was 3.79 square miles, versus 7.81 square miles for older boys - a doubling with age.

Figure 4 shows the four group-mapped areas in the urban site simultaneously. Grade 8-9 girls have by far the smallest geographic range, even less than that of boys and girls in grade 5. Interestingly, among the grade 5 students, girls represented their community as a much larger space than did boys from the same classroom (6.33 versus 3.79 square miles), indicating that girls' spaces do not start out smaller than boys' spaces, but likely become so after puberty. Comparing grade 8-9 girls with their male classmates reveals the substantial relative changes with age in accessible geographic area by sex: girls' self-defined area is only one-third that of boys' (2.62 versus 7.81 square miles).

Community spaces for participants in the rural site are shown in Figures 5-7. The representation of girls' spaces (Figure 5) indicates that contraction of female spatial access with puberty is not solely an urban phenomenon. In this setting, the area outlined by younger girls was 
nearly five times the size of that depicted by older girls (4.13 versus 0.90 square miles). Among boys (Figure 6), a pattern not unlike that in the urban area is observed: boys' geographies expand by nearly 50 percent between grade 5 and grades $8-9$, from 3.81 square miles to 5.46 square miles. Figure 7, which displays the four rural sex and grade group areas simultaneously, reveals a configuration similar to the urban one, but is more accentuated for grade $8-9$ girls. The community area defined by grade $8-9$ girls is only 17 percent that of their grade $8-9$ male classmates, and only about one-fifth that of grade 5 girls or boys.

Within the areas diagrammed by each group, the distribution of spaces plotted by safety rating is shown in Figure 8 . The safety ratings vary greatly by sex and grade and differ by urbanrural area. A distinctive pattern by sex is evident in the urban area: here both younger and older girls rated about 60 percent of spaces on their maps as unsafe, whereas boys in both groups indicated that approximately 40 percent of plotted spaces were unsafe. (This is despite the fact that children in each grade attended the same school.) Although the overall percentage of safe versus unsafe places did not change with age for girls or boys in the urban site, the degree of safety fell markedly with age. Even within the highly restricted area they navigate, grade 8-9 urban girls reported that 19 percent of places were extremely unsafe, versus zero percent among grade 5 girls. Among boys, it was a matter of reduced access to the safest places: grade 8-9 boys rated 12 percent of spaces as extremely safe compared with 36 percent of grade 5 boys.

Contrary to expectation, rural participants rated a smaller overall percentage of mapped spaces as safe than did urban participants. The case was particularly striking for younger children: rural grade 5 girls and boys each rated around 80 percent of plotted spaces as unsafe. Both male and female grade 8-9 rural participants rated around 60 percent of spaces on their respective maps as unsafe.

A notable finding is that none of the girls' groups rated any space in their community as more than "somewhat safe," and every girls' group ranked at least 58 percent of spaces as unsafe. Boys' ratings of community spaces showed much wider variation and generally contained more spaces perceived as safe. Boys' safety ratings differed by urban-rural residence, with rural boys describing a much higher percentage of places as unsafe.

Given the different area sizes portrayed by each group, the density of safe and unsafe places is of interest. Figure 9 indicates the number of places plotted per square mile for each group, overall and by safety rating. This image reveals that in both urban and rural areas, grade 8-9 girls had the greatest density of places plotted. In the urban site, grade 8-9 girls diagrammed 7 unsafe spaces per square mile, nearly twice that of any other urban group, and 4 of these 7 spaces were rated as very or extremely unsafe. Urban grade 5 girls plotted 4 unsafe spaces per square mile, grade 5 boys plotted 3 , and grade $8-9$ boys plotted 2.5 .

In the rural site, grade 8-9 girls depicted 11 places per square mile as somewhat unsafe; grade 5 girls reported 10 unsafe places per square mile (most rated as somewhat unsafe). Grade 5 rural boys diagrammed 4 places per square mile as unsafe, and grade 8-9 rural boys reported only 1.5 unsafe places per square mile.

Despite their higher density of perceived unsafe places, grade 8-9 girls in both sites also had a higher concentration than grade 5 girls of places that were considered somewhat safe. The density of safe spaces perceived by boys did not change significantly with age in either site. 
Group-specific perceptions of various place types (not each individual place) are presented in Figures 10 and 11 by sex and grade. In the urban site (Figure 10), both sex and grade patterns are manifest. Boys reported a number of place types as very or extremely safe, whereas girls did not plot a single place in these two safe categories. Moreover, the number and variety of place types plotted decreases with age for girls, but increases with age for boys - in line with their respective shrinking and expanding geographic areas with age. Younger and older urban girls reported the library, petrol station, and police station as somewhat safe, while older boys described the library and police station as extremely safe (younger boys did not mention these places). Among grade 5 children, the primary school (where the mapping exercise took place) was given a mixed safety rating by girls, but was considered extremely safe by boys; analogously, grade 8-9 girls rated the secondary school (again, the research location) as very unsafe, whereas boys considered it very safe. Clinics were consistently rated as somewhat safe by boys but had mixed safe/unsafe ratings among girls. Most private homes were viewed by girls as somewhat unsafe but by boys as very safe. Transport hubs ("taxi ranks") were considered very unsafe by every group except grade $8-9$ boys, who viewed them as very safe. Urban grade 8-9 boys and girls each reported two extremely unsafe spaces on their maps (girls: bridge and shopping center; boys: river and tavern).

In the rural site (Figure 11), virtually no place was described by any group as extremely or very safe. Here younger children perceived more overall threats than older children. Grade 5 boys and girls each described eight place types in the community as unsafe, although boys rated several of these as less safe than girls did. Rural grade 8-9 girls assigned most place types either a mixed safe/unsafe or a somewhat safe or unsafe rating; older rural boys had the widest distribution of safety ratings. Among grade 8-9 children, boys viewed the primary school as very safe but girls gave it a mixed rating. The secondary school ground was seen by girls as somewhat safe but by boys as extremely unsafe. Older boys also viewed road intersections, the water pump, and the bus stop as very or extremely unsafe; these places were not within the narrow confines of the older rural girls' map.

\section{DISCUSSION}

Most research on community violence does not assess safety perceptions in a disaggregated manner by sex and age, thus limiting insights about the nature and life-course timing of perceived threats. Adolescence is a life stage typically portrayed as offering expanded social, geographic, and intellectual opportunities. In many settings, however, this is a period when attempts to access opportunities and resources may also carry actual and/or perceived risk of harm (Leoschut and Burton 2006). This study found that the spatial geographies of adolescents in KwaZulu-Natal, South Africa change significantly with age and in a diametrically opposite manner by sex.

Group participatory mapping was undertaken with grade 5 and grade 8-9 female and male adolescents living in urban and rural communities. In all places and for all cohorts, the maps showed high levels of perceived insecurity and unsafety, indicating that young people are likely to encounter violence frequently, but differently by age and sex. While boys reported many unsafe places, they also indicated greater access than girls to places they considered safe. Feeling 
unsafe is likely to constrain the exercise of rights and access to services and opportunities, thus threatening both current well-being and future prospects. Girls in both grade cohorts perceived more intimate bodily dangers in their communities than did boys, and these were associated with repeated and systemic reports of vulnerability to sexual assault and rape. Grade 5 urban girls repeated a common theme in speaking about unsafe spaces: people know about them, but no one does anything. As one participant commented about a well-known perpetrator in the area, "people close their doors when the man is raping someone." A particular shop was classified by this group as somewhat safe only because, as girls reported, "children are not raped there." Such commentary reveals a clear need for improved protection against forms of sexual and genderbased violence even among young girls, particularly in a time and place of high HIV/AIDS prevalence.

Although grade 8-9 girls diagrammed much smaller geographic spheres than grade 5 girls, this did not necessarily reflect a subsequent decrease in perceived threats. With age, girls appeared to lose access to space in general, and urban grade 8-9 girls seemed to perceive the majority of spaces and persons as unsafe, indicating a perception that the community itself poses a threat. "Anything can happen anytime," members of the group reported. Participants remarked on what seemed an utter lack of community involvement, which may be a reaction to both the community's failure to provide protection and their own lack of positive interactions with the community as a result of their confined geographies. Urban girls in both grade groups conveyed a sense of helplessness and hopelessness in the community more broadly, without the ability to hold anyone specific accountable.

Younger boys described unsafe physical infrastructure and places lacking uniformed security personnel as unsafe, while older boys identified unsafe spaces as those marked by maleon-male violence, robbery, theft, and drug use. Grade 5 rural boys were far more concerned with natural hazards - snakes, falling rocks, rivers that would flood, dangerous roads - whereas grade 5 boys in the urban community frequently identified social behaviors and violence-alcohol and drug abuse and fighting - as concerns. Although the expanded personal geographies of grade 8-9 boys introduced new spheres of opportunity, they also resulted in exposure to violent crime and the potential for becoming participants in or victims of such crime - an indication of how cycles within communities are reproduced, transforming young men from witnesses or victims to possible perpetrators.

Historically in South Africa, the structural legacies of apartheid-era policies and patterns of urban political violence fractured numerous families and undermined relationships between adolescents and adults (Reynolds 1997). Today, the remnants of that history are coupled with the widespread incidence of HIV, which has left a large number of young people with one or both parents who are sick or deceased. In addition to the further weakening of generational and family ties as a result of AIDS, the official end of apartheid saw the waning of opportunities for young people to engage in political activism for human and civil rights. Increasingly disenfranchised and silenced in the midst of a rapidly globalizing, commodified, and media-oriented society that further divides the generations, South African adolescents now have fewer opportunities for attaining community respect and participation. This is a social and democratic deficit that renders adolescents less able to cope constructively with violence and may lead them to engage in 
violence and crime themselves. It is in this context of eroding forms of adolescent citizenship and waning intergenerational cohesion that efforts to understand perceptions of violence from the perspective of adolescents themselves are important. The largely unexamined impacts of structural, community, and interpersonal violence in adolescent populations should be recognized as a potential cause of insecurity that may create lifelong deficits in capabilities and protective assets, feed cycles of victimhood and perpetration, and cause a variety of negative mental health consequences (Dawes and Ward 2011; Patel et al. 2007).

The exploration of actions to increase the availability of safe social spaces in the community for adolescent girls and boys is clearly needed. In such spaces, young citizens would have a secure and regularly accessible place to gather, learn, and play, not only within the school setting but also in the community, in order to translate skills and knowledge into developmental competence (Brady 2003; Mensch, Bruce, and Greene 1998). In contexts such as South Africa where education levels are high, such safe spaces are fundamental to transforming education into functional and productive capabilities, defined by Sen (2001) as "the ability - the substantive freedom - of people to lead the lives they have reason to value" (p. 293). Although it is encouraging that attention to these "safe spaces" is being explored for girls in low- and middleincome countries (Brady 2005; Poverty Action Lab 2007; Dunbar et al. 2010; Austrian et al. 2012; Underwood and Schwandt 2011; Erulkar et al. 2012; Bandiera et al. 2012), there are still no definitive solutions, and boys' increasing exposure at puberty to violence and substance abuse has received little attention in low- and middle-income countries (Patton 2011).

The simple but powerful mapping tool used in this study can directly inform a holistic community effort to reduce violence, allowing participants to understand and address insecurity and crime as mediated and fueled by generational and gender-based hierarchies within society. The more frequently such phenomena can be portrayed and understood as multiple, overlapping, yet identifiable and addressable epidemics occurring in the same space, the better able communities will be to tackle these problems. Small-scale participatory techniques like this one tailored to children and adolescents are emerging methods that still need to be refined. The school classroom itself, while crucial to the success of the project in this context where the majority of children attend school, was a difficult setting in which to conduct such research because the time for assembling focus groups and for drawing and labeling the maps was limited and did not permit as much follow-up or in-depth discussion as we had hoped. Systematizing and categorizing findings across the set of maps was difficult because the parameters and dimensions of the community, as well as symbols used to depict local places, were defined by participants themselves and thus varied. In addition, this study was not longitudinal, so we cannot say that the subsequent experiences of grade 5 children will necessarily reflect those of their grade 8-9 contemporaries. And the sample size for the study was small. Nevertheless, participatory mapping proved to be a low-cost, powerful tool for revealing both safe and unsafe sex- and agespecific spaces within urban and rural communities. This tool can easily be used in conjunction with larger projects for assessing perceptions of violence and creating targeted programs for adolescents. Researchers can collaborate with specific groups in the community to help participants identify factors that are amenable to policy and program intervention. Such initiatives must begin by recognizing the potential for sex, age, race/ethnic, and socioeconomic 
inequalities to contribute to the chronic insecurity experienced by particular groups. Future research should also test the feasibility of involving underrepresented subpopulations, as we attempted to do in this exercise.

This project unveiled a range of perceptions of safety and risk in the everyday lives of adolescents. When groups affected by violence - in this case adolescents - have only weak social support systems and are civically disenfranchised, their claims to justice and safety are easily ignored by politicians, the police, and other decisionmakers. However, when such claims take visible form and are portrayed using maps that community members and political actors can identify as their own spaces, they give voice to less powerful groups (Chambers 1992; Cornwall and Jewkes 1995). Maps often have political clout - they are a primary language of policy and politicians. As such, when presented to local leaders, maps have the potential to command greater attention and could help bring together disparate actors responsible for the protection of young people, such as police, judicial institutions, health and social service agencies, school administrators, and private security forces. Such initiatives should take root in more communities, and the findings should drive, and be met by, national policies to support local efforts at ensuring the safety of adolescents. An initial concrete step in this direction is harnessing existing spaces in the community that could function as reliably available age- and sex-specific safe places. For example, a local library could be designated two afternoons per week as a female pre-adolescent space; a youth center could be reserved as a girls-only space on Saturday mornings and a boys-only space on Saturday afternoons. In such spaces young people can gather, learn, and build healthy social support networks that can be drawn upon in times and places of danger or insecurity. This ability seems particularly crucial as they negotiate the development stage of puberty, a time when personal geographies appear to change drastically and have the ability to influence - for better or worse - the course of their future lives. 


\section{REFERENCES}

Aneshensel, C. S., \& Sucoff, C. A. (1996). The neighborhood context of adolescent mental health. Journal of health and social behavior, 293-310.

Assaad, R., Levison, D., \& Zibani, N. (2010). "The effect of domestic work on girls' schooling: Evidence from Egypt." Feminist Economics 16(1): 79-128.

Austrian, K., Hewett, P., Jackson, N., Soler-Hampejsek, E. (2012). " Adolescent Girls Empowerment Program." <http://www.popcouncil.org/projects/353_ZambiaAGEP.asp>.

Bandiera O, Buehren N, Burgess R, Goldstein M, Gulesci S, Rasul I, Sulaimany M. (2012). "Empowering Adolescent Girls: Evidence from a Randomized Control Trial in Uganda." <http://econ.lse.ac.uk/staff/rburgess/wp/ELA.pdf>.

Barker, Gary. (2005). Dying to Be Young. London: Routledge.

Bennett, G. G., McNeill, L. H., Wolin, K. Y., Duncan, D. T., Puleo, E., \& Emmons, K. M. (2007). Safe to walk? Neighborhood safety and physical activity among public housing residents. PLoS Medicine, 4(10), e306.

Brady, Martha. (2003). "Safe spaces for adolescent girls." Background document to Adolescent and Youth Sexual and Reproductive Health: Charting Directions for a Second Generation of Programming.. New York: UNFPA and Population Council, pp. 155-176.

- (2005). "Creating safe spaces and building social assets for young women in the developing world: A new role for sports." Women's Studies Quarterly 33(1/2): 35-49.

Breinbauer, Cecilia. (2005). Youth: Choices and Change. Promoting Healthy Behaviors in Adolescents. Washington, D.C.: PAHO.

Brookes, H., \& Higson-Smith, C. (2004). "Responses to gender-based violence in schools." In Richter, L. M., Dawes, A., \& Higson-Smith, C. (eds.) Sexual Abuse of Young Children in Southern Africa. Pretoria: HSRC Press.

Chambers, R. (1992). "Rural appraisal: Rapid, relaxed and participatory." Institute for Development Studies Discussion Paper No. 311.

_ (1994). "The origins and practice of participatory rural appraisal." World Development 22(7): 953-969.

- (1997). Whose Reality Counts?: Putting the First Last. Intermediate Technology Publications Ltd (ITP).

Choby, A. A., Dolcini, M. M., Catania, J. A., Boyer, C. B., \& Harper, G. W. (2012). "African American adolescent females' perceptions of neighborhood safety, familial strategies, and sexual debut." Research in Human Development 9(1): 9-28.

CIET Africa \& Greater Johannesburg Southern Metropolitan Local Council. (2000). Beyond Victims and Villains: The Culture of Sexual Violence in South Johannesburg. Johannesburg: Southern Metropolitan Local Council.

Cornwall, A. and Jewkes, R. (1995). "What is participatory research?" Social Science \& Medicine 41(12): 1667-1676. 
Cottam, H. (1994) "The death of the clinic?: Participatory Urban Appraisal (PUA) in a Dominican barrio," RRA Notes 21: 28-33.Creswell, J. W. (1998). Qualitative Inquiry and Research Design: Choosing among Five Traditions. Thousand Oaks: Sage.

Cummins, S., Curtis, S., Diez-Roux, A. V. and Macintyre, S. (2007). "Understanding and representing 'place' in health research: A relational approach." Social Science \& Medicine 65(9): 1825-1838.

Das, V. (2007). Life and Words: Violence and the Descent into the Ordinary. Berkeley: University of California Press.

Davison, K. K., \& Jago, R. (2009). Change in parent and peer support across ages 9 to 15 years and adolescent girls' physical activity. Med Sci Sports Exerc,41(9), 1816-25.

Dawes, A., \& Ward, C. (2011). Violence and violence prevention: New roles for child and adolescent mental health practitioners. Journal of Child \& Adolescent Mental Health, 23(1), 1-4.

Dunbar, M. S., M. C. Maternowska, et al. (2010). "Findings from SHAZ!: A Feasibility Study of a Microcredit and Life-Skills HIV Prevention Intervention to Reduce Risk Among Adolescent Female Orphans in Zimbabwe." Journal of Prevention \& Intervention in the Community 38(2): 147-161.

Dupéré, V., Leventhal, T., \& Vitaro, F. (2012). "Neighborhood processes, self-efficacy, and adolescent mental health." Journal of Health and Social Behavior 53(2): 183-198.

Erulkar, A., Ferede, A., Girma, W., \& Ambelu, W. (2012). "Evaluation of "Biruh Tesfa" (Bright Future) Program for vulnerable girls in Ethiopia." Vulnerable Children and Youth Studies, (ahead-of-print), 1-11.

Galambos, N. L., Berenbaum, S. A., \& McHale, S. M. (2009). Gender development in adolescence. Handbook of adolescent psychology.

Gomez, J. E., Johnson, B. A., Selva, M., \& Sallis, J. F. (2004). "Violent crime and outdoor physical activity among inner-city youth." Preventive Medicine 39(5): 876-881.

Hilbrecht, M., Zuzanek, J., \& Mannell, R. C. (2008). Time use, time pressure and gendered behavior in early and late adolescence. Sex Roles, 58(5-6), 342-357.

Human Rights Watch (2001). "Scared at school: Sexual violence against girls in South African schools." New York: Human Rights Watch.

Jewkes, R. (2013). "Intimate partner violence as a risk factor for mental health problems in South Africa." In C. Garcia-Moreno \& A. Riecher-Rössler (Eds.), Violence Against Women and Mental Health. Basel: Karger.

Jewkes, R., \& Abrahams, N. (2002). The epidemiology of rape and sexual coercion in South Africa: an overview. Social Science \& Medicine, 55(7), 1231-1244.

Jewkes, R. K., Dunkle, K., Nduna, M., \& Shai, N. (2010). "Intimate partner violence, relationship power inequity, and incidence of HIV infection in young women in South Africa: a cohort study." Lancet 376(9734): 41-48.

Jewkes, R.K., Levin, J., Mbananga, N., and Bradshaw, D. (2002). Rape of girls in South Africa. The Lancet 359(9303): 319-320. 
Jewkes, R., Sikweyiya, Y., Morrell R., and Dunkle, K. (2009). "Understanding Men's Health and Use of Violence: Interface of Rape in HIV in South Africa." MRC. <http://www.mrc.ac.za/gender/interfaceofrape\&hivsarpt.pdf>. Accessed 24 March 2013.

Kim, J. (2010). "Influence of neighbourhood collective efficacy on adolescent sexual behaviour: variation by gender and activity participation." Child: Care, Health and Development 36(5): 646-654.

Kimm, S. Y., Glynn, N. W., Kriska, A. M., Barton, B. A., Kronsberg, S. S., Daniels, S. R., ... \& Liu, K. (2002). Decline in physical activity in black girls and white girls during adolescence. New England Journal of Medicine 347(10): 709-715.

Kleinman, A. (2000). "The violences of everyday life: The multiple forms and dynamics of social violence." In V. Das, A. Kleinman, M. Ramphele \& P. Reynolds (eds.), Violence and Subjectivity. Berkeley: University of California Press.

Lary, H., Maman, S., Katebalila, M., \& Mbwambo, J. (2004). Exploring the association between HIV and violence: young people's experiences with infidelity, violence and forced sex in Dar es Salaam, Tanzania. International Family Planning Perspectives, 200-206.

Latour, B. (1996). "On actor-network theory—a few clarifications." Soziale Welt-Zeitschrift fur Sozialwissenschaftliche Forschung und Praxis 47(4): 369

Leach, F., and Humphreys, S. (2007). "Gender violence in schools: taking the 'girls-as-victims' discourse forward." Gender \& Development 15(1): 51-65.

Leoschut, L., and Burton, P. (2006). How Right the Rewards? Results of the 2005 National Youth Victimisation Study. Cape Town.

Lozano, R., Naghavi, M., Foreman, K., AlMazroa, M. A., \& Memish, Z. A. (2013). "Global and regional mortality from 235 causes of death for 20 age groups in 1990 and 2010: a systematic analysis for the Global Burden of Disease Study 2010." Lancet 381(9867): 628-628.

Mensch, B., Bruce, J., and Greene, M. (1998). The Uncharted Passage: Girls' Adolescence in the Developing World. New York: Population Council.

Mirsky, J. (2003). Beyond Victims and Villains: Addressing Sexual Violence in the Education Sector. London: Panos Institute.

Mitchell, C. (2005). "Mapping a Southern African girlhood in the age of AIDS," in L. Chisholm, \& J. September (eds.), Gender Equity in South African Education 1994-2004: Perspectives from Research, Government and Unions: Conference Proceedings. HSRC Press. Pp. 92-112.

Mitchell, C. (2011). Doing Visual Research. Sage.

Mitchell, C., Moletsane, R., Stuart, J., Buthelezi, T., \& De Lange, N. (2005). Taking pictures / Taking action! Using photo-voice techniques with children. ChildrenFIRST 9(60): 27-31.

Mitchell, C., Reid-Walsh, J., Blaeser, M. \& Smith, A. (1998). "Who cares about girls?" Centering on the Margins: The Evaded Curriculum, 169-176. Canadian Association for the Study of Women and Education, May 31-June 1. Ontario: University of Ottawa. 
Moffett, H. (2006). "'These women, they force us to rape them': Rape as narrative of social control in post-Apartheid South Africa." Journal of Southern African Studies 32(1): 129144.

Morrell, R. (1998). "Of boys and men: masculinity and gender in Southern African studies." Journal of Southern African Studies 24(4): 605-630.

MRC-UNISA. (2010). A Profile of Fatal Injuries in South Africa: The National Injury Mortality Surveillance System. Cape Town: Medical Research Council.

Mukherjee, N. (1993). Participatory rural appraisal (Vol. 1). www.conceptpub.com.

Murdoch, J. (1998). "The spaces of actor network theory." Geoforum 29(4): 357-374.

Naude, C., Prinsloo, J., and Ladikos, A. (2006). Experiences of crime in thirteen African countries: results from the international crime victim survey. Turin: UNODC-UNICRI

Norton, A. (1994). "Observations on urban applications of PRA methods from Ghana and Zambia: participatory poverty assessments," RRA Notes, 21, pp. 55-57.

Patel, V., Flisher, A. J., Hetrick, S., \& McGorry, P. (2007). Mental health of young people: a global public-health challenge. The Lancet, 369(9569), 1302-1313.

Patton, G. C. (2011). Global Pattern of Mortality in Young People. United Nations, Department of Economic and Social Affairs, Population Division. http://www.un.org/esa/population/ meetings/egm-adolescents/p02_patton.pdf.

Pinheiro, P. S. (2006). "World report on violence against children." New York: United Nations.

Poverty Action Lab. (2007). "Empowering Girls in Rural Bangladesh." <http://www.povertyactionlab.org/evaluation/empowering-girls-rural-bangladesh>.

Power, R., Langhaug, L., \& Cowan, F. (2007). "But there are no snakes in the wood": risk mapping as an outcome measure in evaluating complex interventions. Sexually transmitted infections, 83(3), 232-236.

Reynolds, P. (1997). "The ground of all making: State violence, the family and political activists." In V. Das, A. Kleinman, M. Ramphele \& P. Reynolds (eds.), Violence and Subjectivity. Berkeley: University of California Press.

Richter, L. M., Dawes, A., \& Higson-Smith, C. (Eds.). (2004). Sexual Abuse of Young Children in Southern Africa. HSRC Press.

Seedat, M., Van Niekerk, A., Jewkes, R., Suffla, S., \& Ratele, K. (2009). "Violence and injuries in South Africa: prioritising an agenda for prevention." Lancet 374(9694): 1011-1022.

Sen, A. (2001). Development as Freedom. New York: Oxford University Press.

Shields, N., Fieseler, C., Gross, C., Hilburg, M., Koechig, N., Lynn, R., \& Williams, B. (2010). "Comparing the effects of victimization, witnessed violence, hearing about violence, and violent behavior on young adults." Journal of Applied Social Science 4(1): 79-96.

Singh, G. K., Azuine, R. E., Siahpush, M., \& Kogan, M. D. (2012). "All-cause and causespecific mortality among US youth: socioeconomic and rural-urban disparities and international patterns." Journal of Urban Health 90(3): 388-405. 
Stromquist, Nelly P. (1996). "Mapping gendered spaces in third world educational interventions." Social Cartography: Ways of Seeing Social and Educational Change, P. Rolland (ed.). New York: Garland Publishing.

Tidball, K., and Stedman, R. (2013). "Positive dependency and virtuous cycles: from resource dependence to resilience in urban social-ecological systems." Ecological Economics. 86: 292-299.

Townsend, L., Jewkes, R., Mathews, C., Johnston, L. G., Flisher, A. J., Zembe, Y., \& Chopra, M. (2011). "HIV risk behaviours and their relationship to intimate partner violence (IPV) among men who have multiple female sexual partners in Cape Town, South Africa." AIDS and Behavior 15(1): 132-141.

Underwood, C.\& Schwandt, H. (2011). "Go Girls! Initiative Research Findings Report." Johns Hopkins Bloomberg School of PublicHealth/Center for Communication Programs. Baltimore, MD.

Upchurch, D. M., Aneshensel, C. S., Sucoff, C. A., \& Levy-Storms, L. (1999). Neighborhood and family contexts of adolescent sexual activity. Journal of Marriage and the Family, 920-933.

Wellings K, Collumbien M, Slaymaker E, et al. (2006). "Sexual behavior in context: a global perspective." Lancet 368(9548): 1706-1728.

Whitaker, R. C. (2010). The infancy of obesity prevention. Archives of pediatrics \& adolescent medicine, 164(12), 1167.

Whyte, W. F. E. (1991). Participatory Action Research. Thousand Oaks, CA: Sage Publications, Inc.

Winton, A. (2005). Youth, gangs and violence: analysing the social and spatial mobility of young people in Guatemala City. Children's Geographies, 3(2), 167-184.

Zona, K., \& Milan, S. (2011). Gender differences in the longitudinal impact of exposure to violence on mental health in urban youth. Journal of youth and adolescence, 40(12), 1674-1690. 


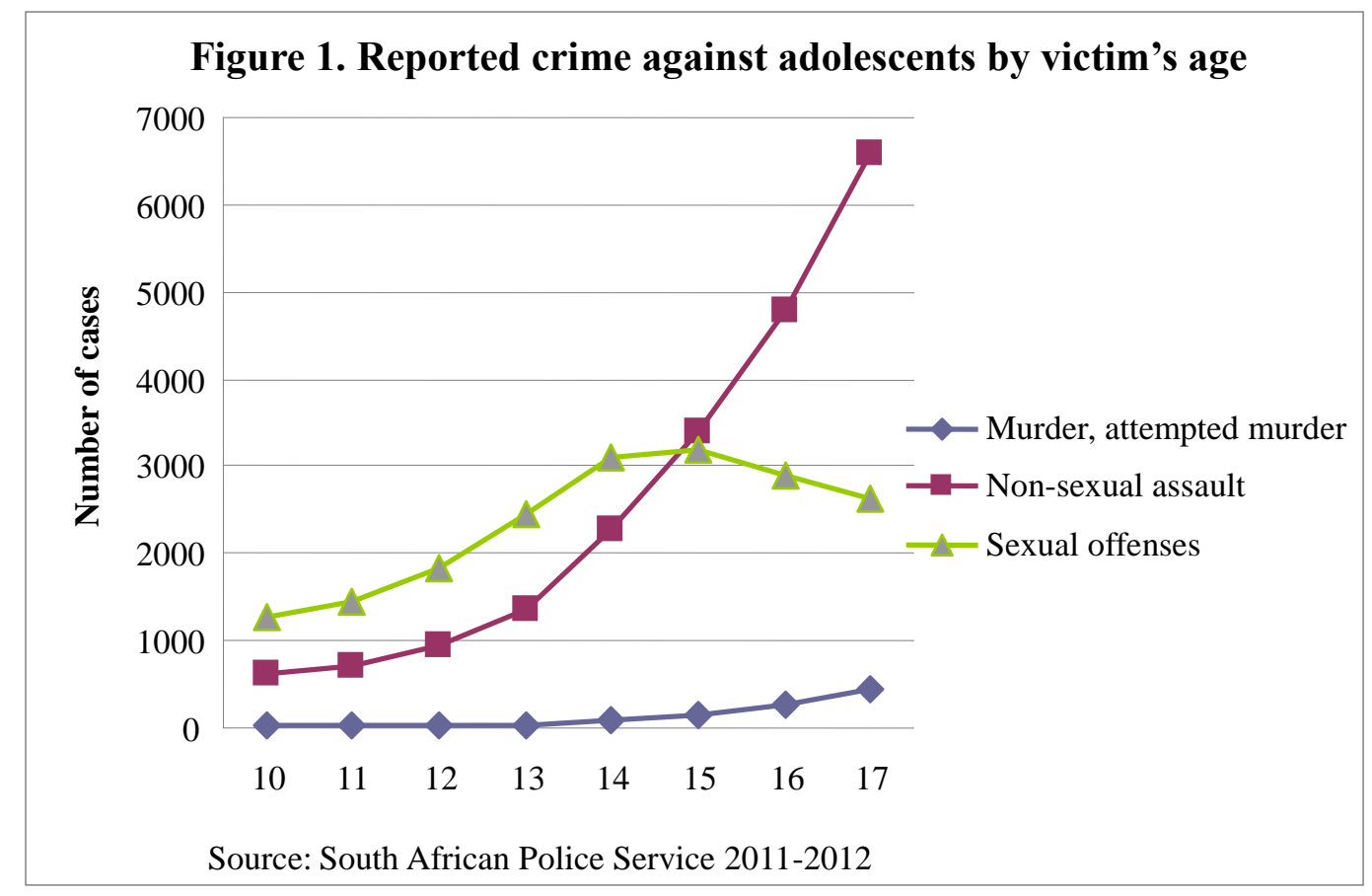

Figure 2. Urban spatial area for girls by grade

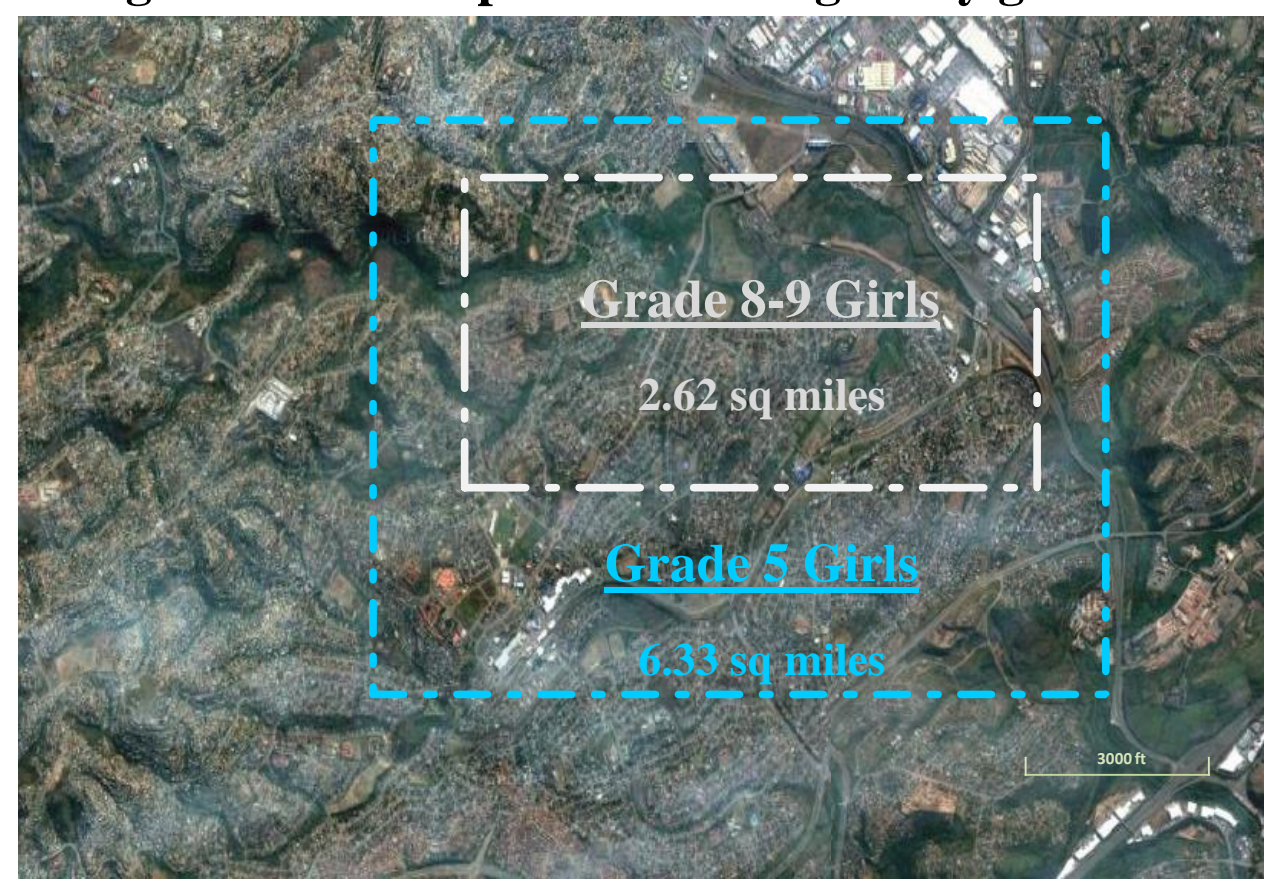


Figure 3. Urban spatial area for boys by grade

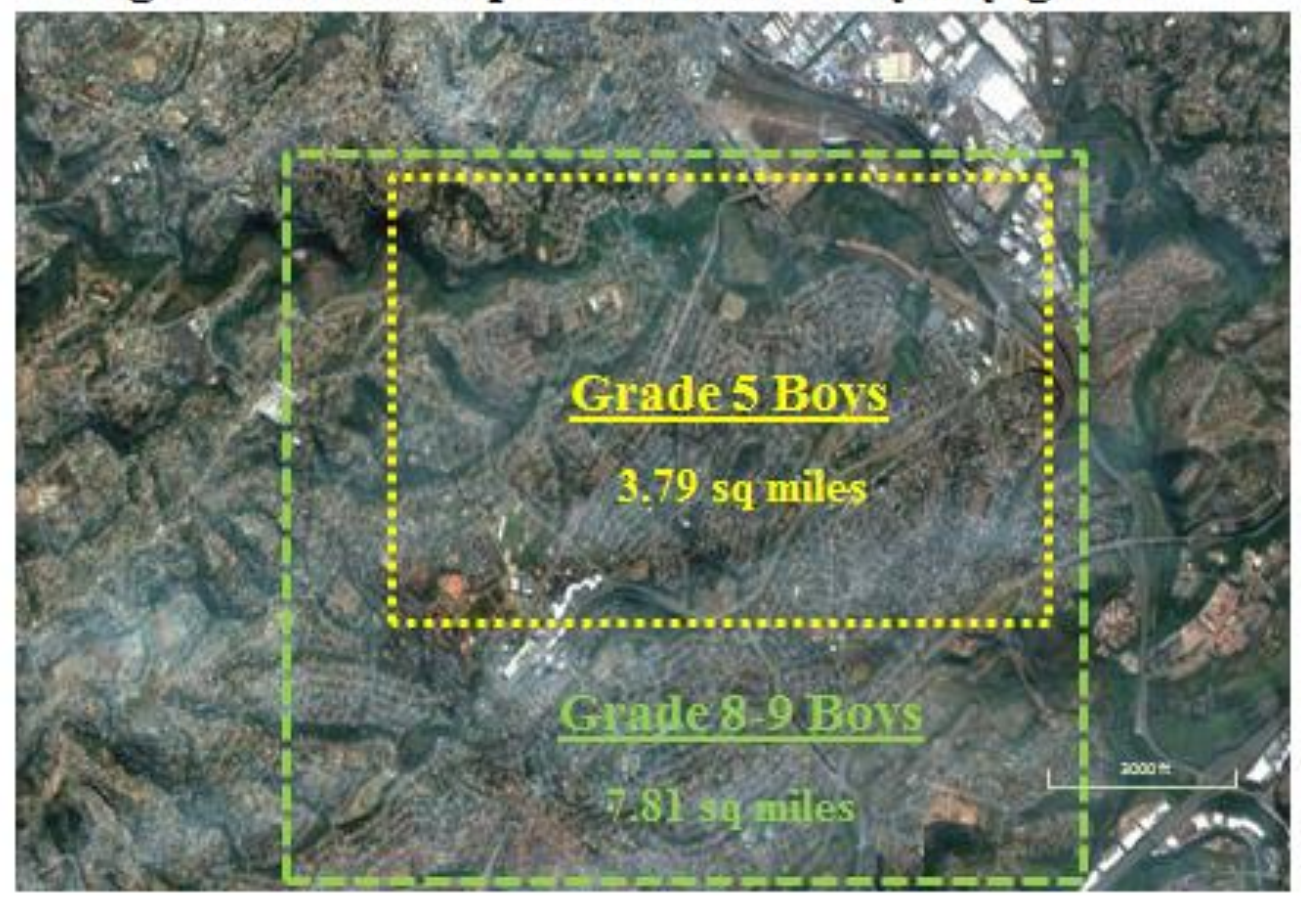

Figure 4. Urban spatial area by sex and grade

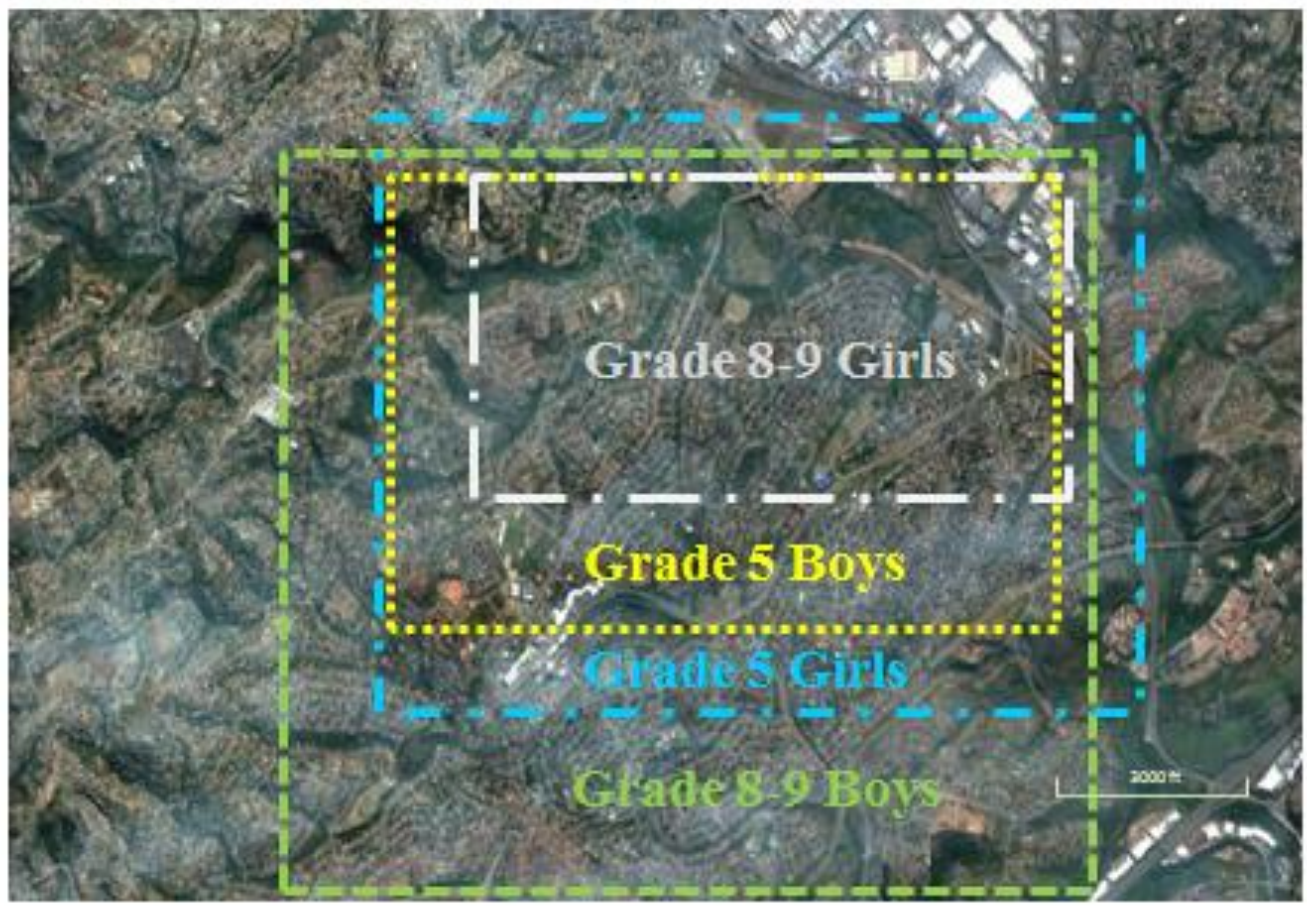


Figure 5. Rural spatial area for girls by grade

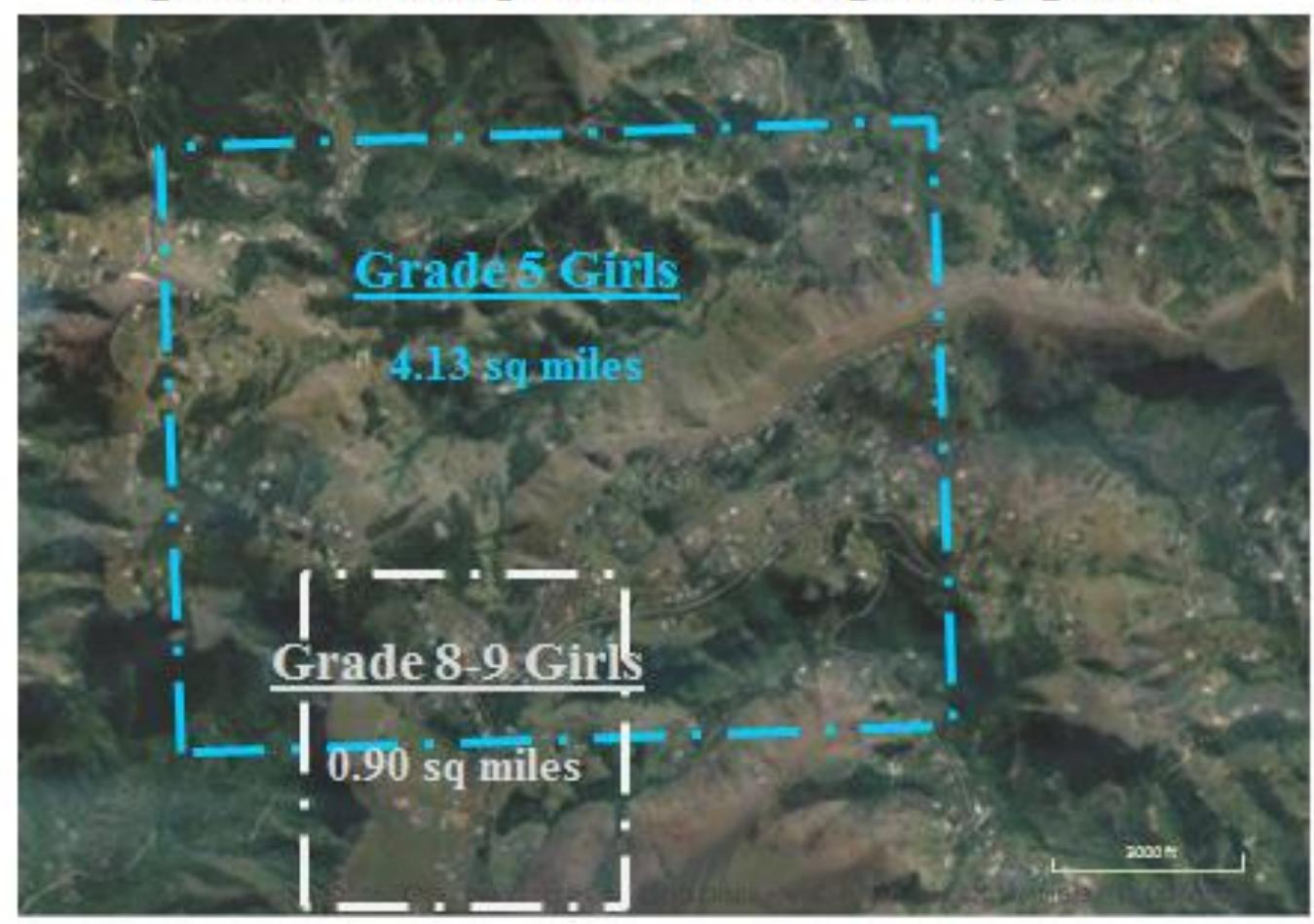

Figure 6. Rural spatial area for boys by grade

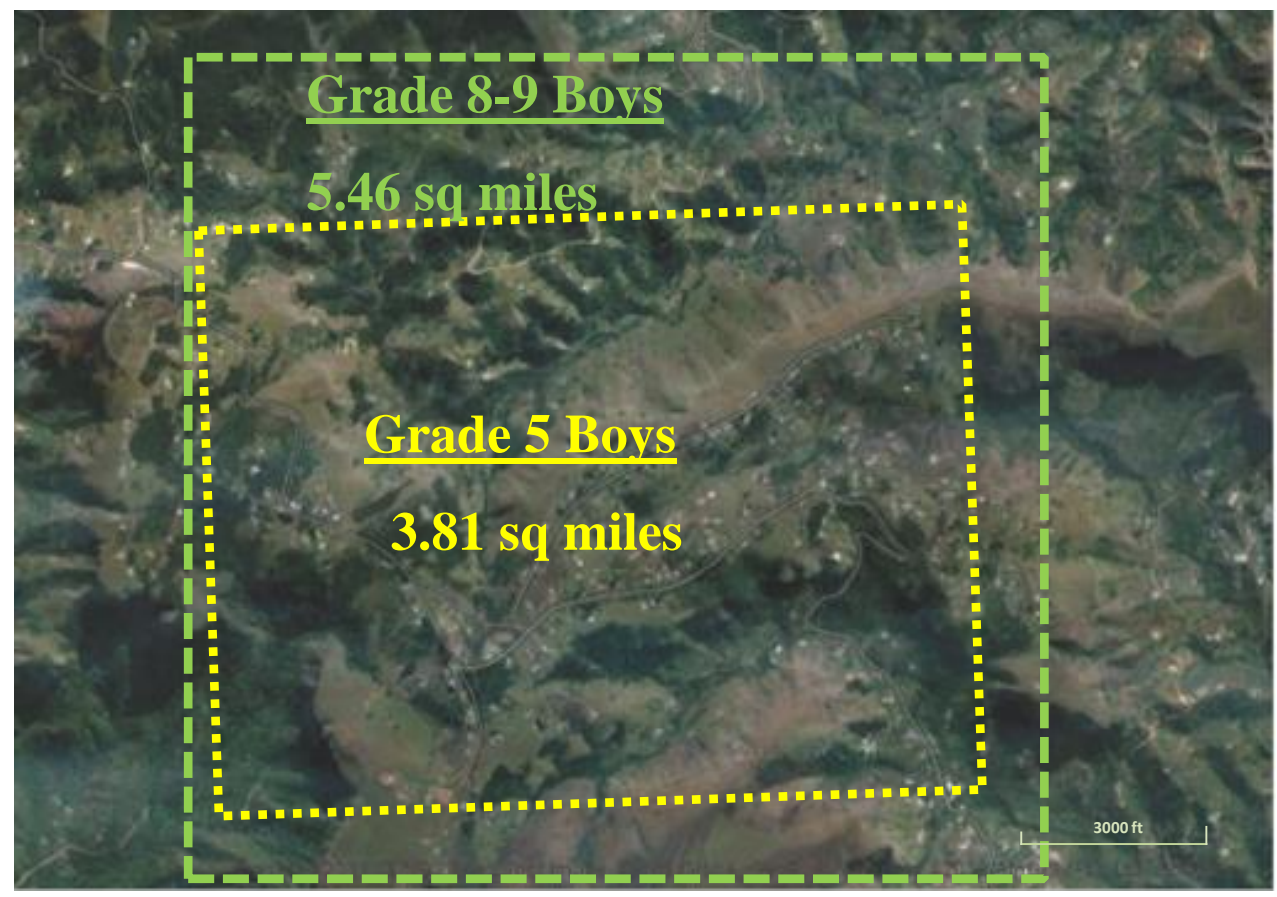


Figure 7. Rural spatial area by sex and grade

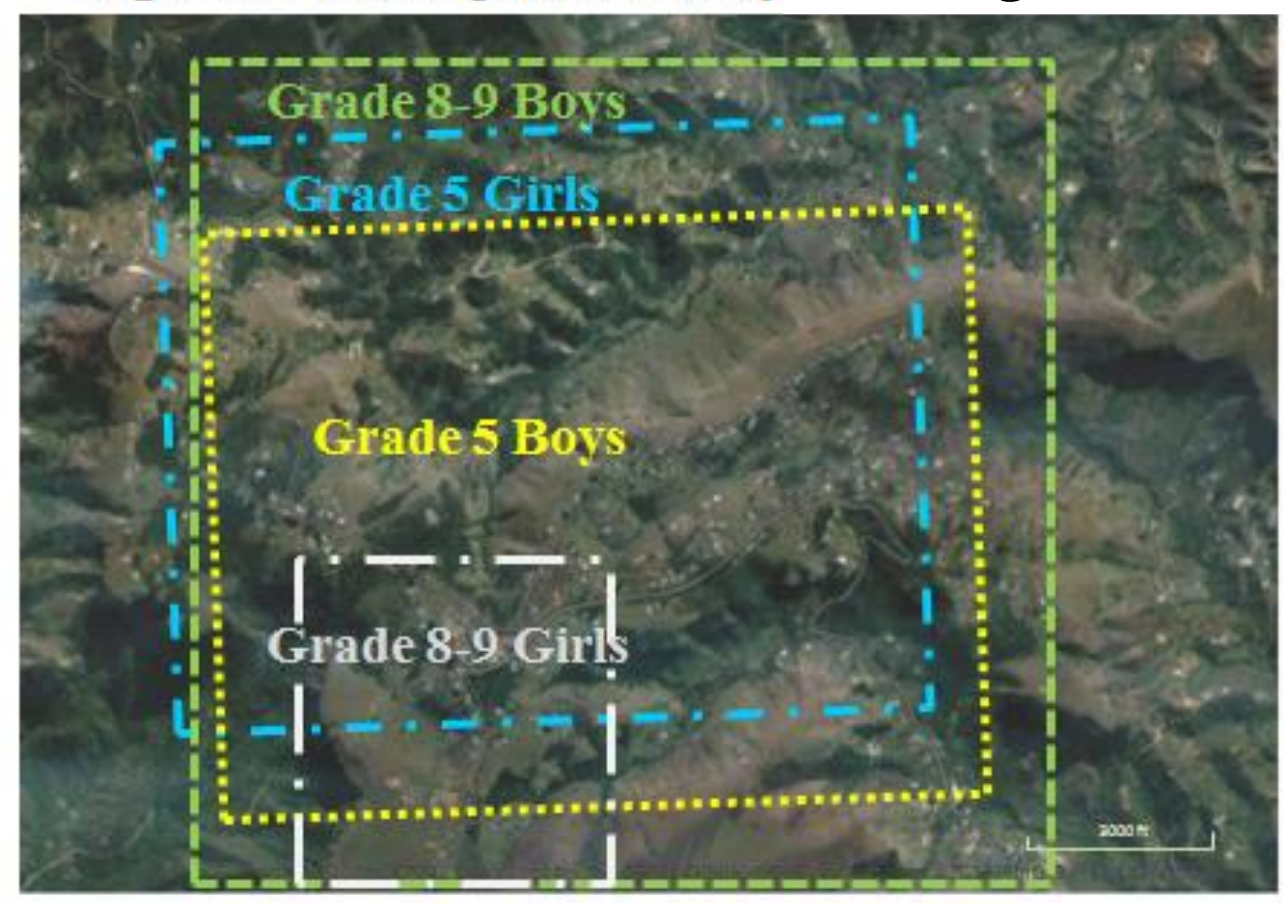




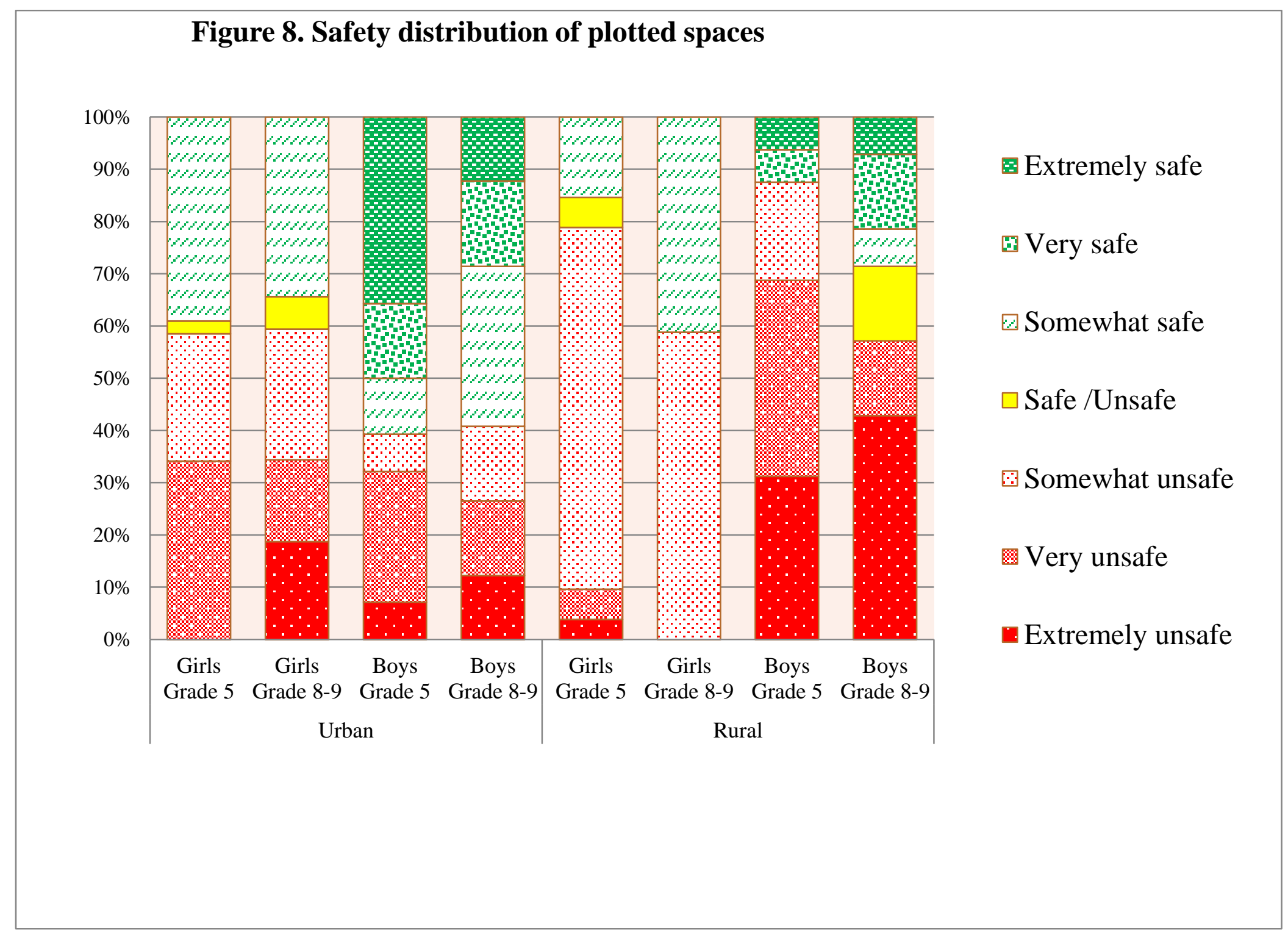


Figure 9. Density of safe / unsafe places by sex and urban-rural residence

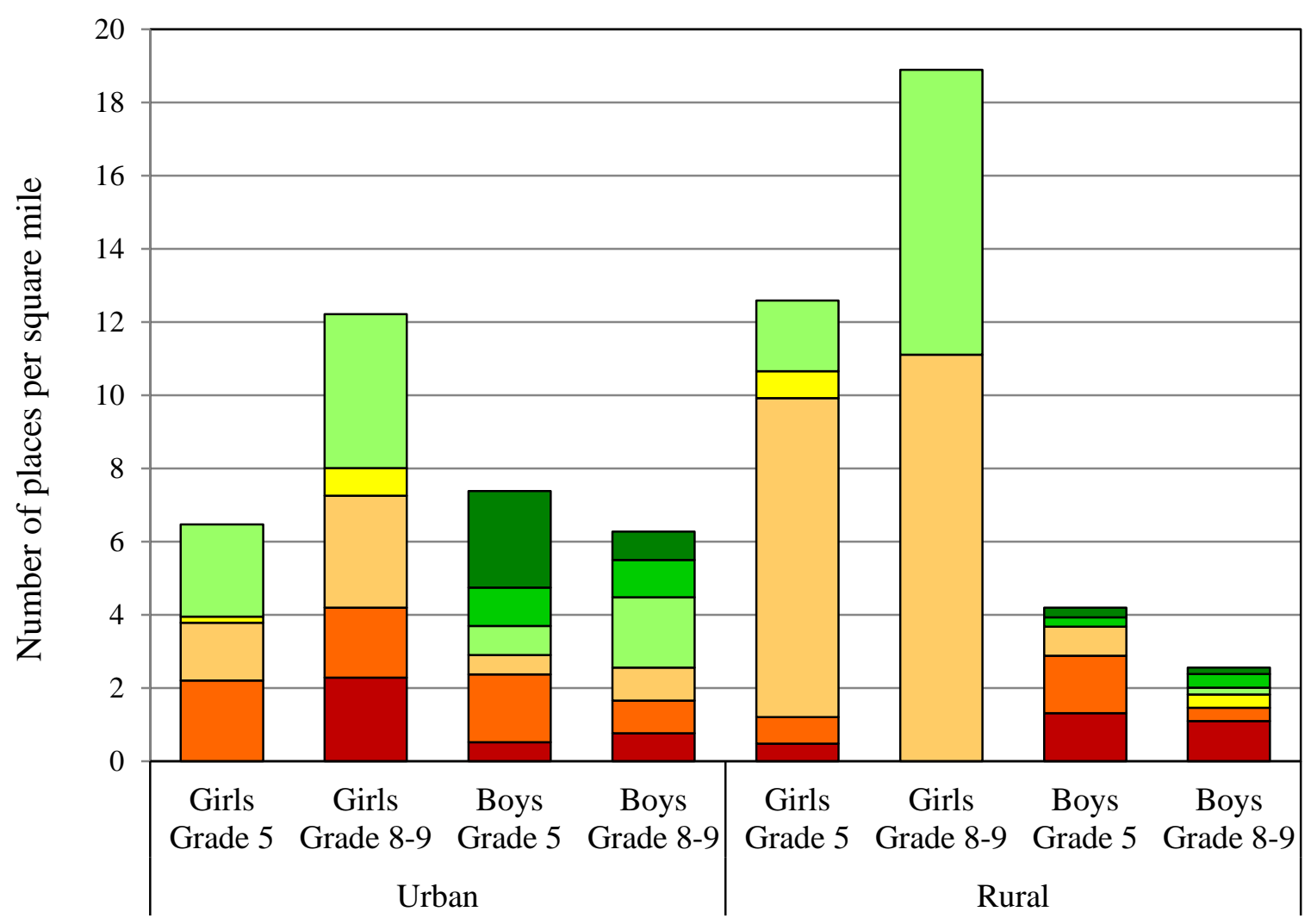

$\square$ Extremely safe

$\square$ Very safe

$\square$ Somewhat safe

$\square$ Safe / Unsafe

$\square$ Somewhat unsafe

$\square$ Very unsafe

$\square$ Extremely unsafe 
Figure 10. Urban place type safety ratings by sex and grade

\begin{tabular}{|c|c|c|c|c|c|c|c|}
\hline & $\begin{array}{l}\text { Extremely } \\
\text { safe }\end{array}$ & Very safe & $\begin{array}{c}\text { Somewhat } \\
\text { safe }\end{array}$ & Safe / unsafe & $\begin{array}{c}\text { Somewhat } \\
\text { unsafe }\end{array}$ & Very unsafe & $\begin{array}{c}\text { Extremely } \\
\text { unsafe }\end{array}$ \\
\hline $\begin{array}{c}\text { GIRLS } \\
\text { Grade } \\
5\end{array}$ & & & $\begin{array}{c}\text { Library } \\
\text { Petrol station } \\
\text { Police station } \\
\text { Crèche } \\
\text { Salon }\end{array}$ & $\begin{array}{c}\text { Clinic } \\
\text { Primary school } \\
\text { Church } \\
\text { Spaza shops } \\
\text { Swimming pool }\end{array}$ & Bushes & $\begin{array}{c}\text { Taxi ranks } \\
\text { River } \\
\text { Railway } \\
\text { School grounds } \\
\text { Worker hostel } \\
\text { Playing field }\end{array}$ & \\
\hline $\begin{array}{c}\text { Grade } \\
8-9\end{array}$ & & & $\begin{array}{c}\text { Library } \\
\text { Petrol station } \\
\text { Police station } \\
\text { Church }\end{array}$ & $\begin{array}{c}\text { Clinic } \\
\text { Primary school } \\
\text { Phone shop }\end{array}$ & $\begin{array}{c}\text { River } \\
\text { Railway } \\
\text { Intersection } \\
\text { Homes }\end{array}$ & $\begin{array}{c}\text { Taxi ranks } \\
\text { Secondary school } \\
\text { Spaza shops }\end{array}$ & $\begin{array}{c}\text { Bridge } \\
\text { Shopping center }\end{array}$ \\
\hline $\begin{array}{c}\text { BOYS } \\
\text { Grade } \\
5\end{array}$ & $\begin{array}{c}\text { Primary school } \\
\text { Animal pen } \\
\text { Police station }\end{array}$ & & $\begin{array}{l}\text { Clinic } \\
\text { Crèche }\end{array}$ & $\begin{array}{l}\text { Churches } \\
\text { Spaza shops }\end{array}$ & Playing field & Taxi ranks & Bridge \\
\hline $\begin{array}{c}\text { Grade } \\
8-9\end{array}$ & $\begin{array}{c}\text { Library } \\
\text { Police station }\end{array}$ & $\begin{array}{c}\text { Homes } \\
\text { School ground } \\
\text { Secondary school } \\
\text { Church } \\
\text { Taxi ranks }\end{array}$ & Clinic & $\begin{array}{l}\text { Primary school } \\
\text { Playing field } \\
\text { Animal pen }\end{array}$ & Intersection & $\begin{array}{c}\text { Bridge } \\
\text { Swimming pool }\end{array}$ & $\begin{array}{l}\text { River } \\
\text { Tavern }\end{array}$ \\
\hline
\end{tabular}


Figure 11. Rural place type safety ratings by sex and grade

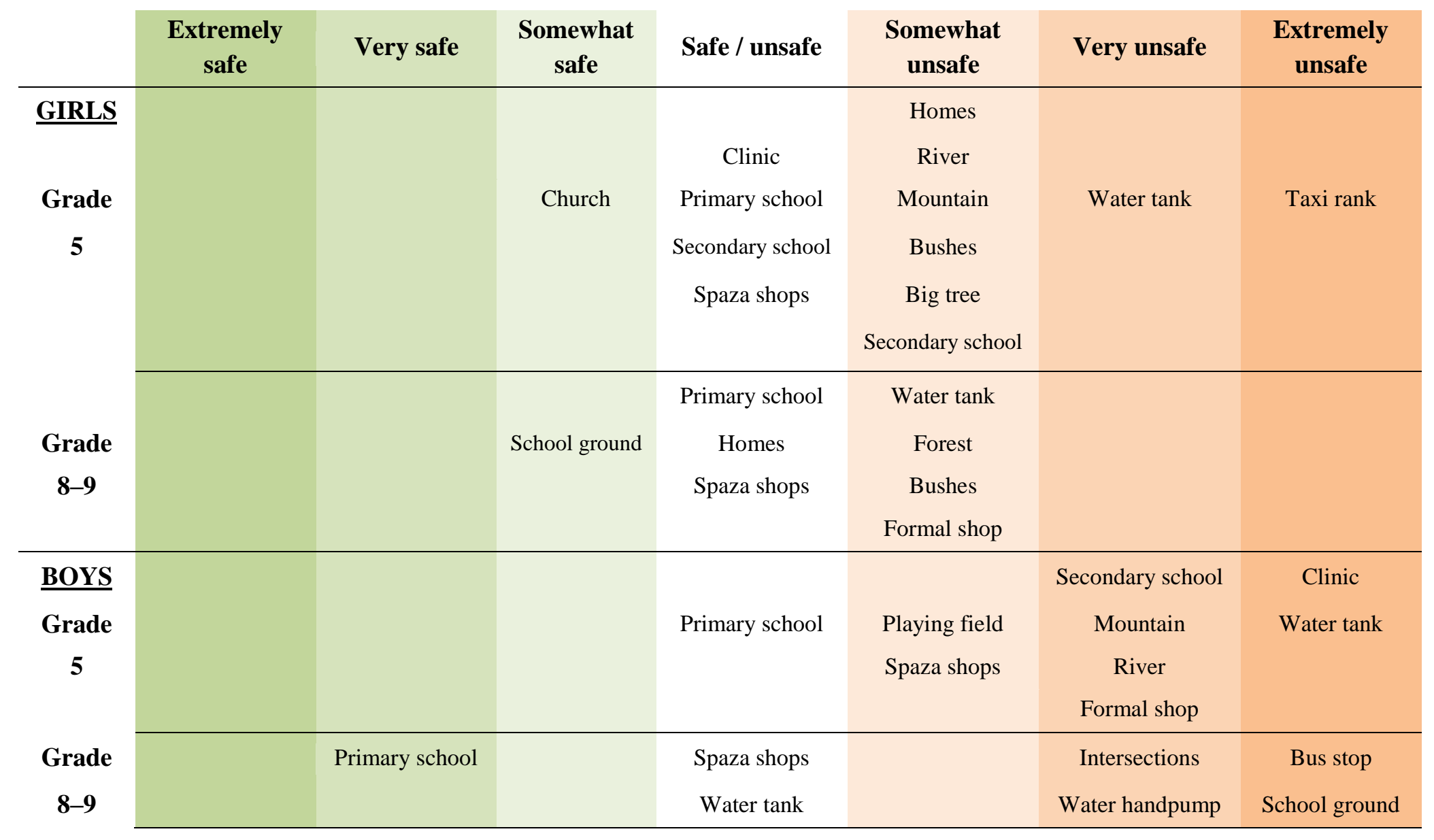




\section{Recent Poverty, Gender, and Youth Working Papers}

Working papers are distributed electronically. When a new paper is published, subscribers are notified by e-mail and a link to the paper is provided.

To subscribe to the Poverty, Gender, and Youth working paper e-mail notification list, please send your request to pgywp@popcouncil.org.

PDFs of working papers are available at www.popcouncil.org/publications/wp.asp

2013

25

Kelly K. Hallman, Nora J.

Kenworthy, Judith Diers, Nick Swan, and Bashi Devnarain, "The

Contracting World of Girls at

Puberty: Violence and Gender-

Divergent Access to the Public

Sphere among Adolescents in South

Africa."

2012

24 Rania Roushdy, Maia Sieverding, and Hana Radwan, "The impact of water supply and sanitation on child health: Evidence from Egypt."

2011

23 Judith Bruce, Nicole Haberland, Amy Joyce, Eva Roca, and Tobey Nelson Sapriano, "First generation of gender and HIV programs: Seeking clarity and synergy."

22 Ghada Barsoum, Nadia Rifaat, Omaima El-Gibaly, Nihal Elwan, and Natalie Foricer, "National efforts toward FGM-free villages in Egypt: The evidence of impact."

\section{0}

21 Ashish Bajracharya, "The nature of mothers' work and children's schooling in Nepal: The influence of income and time effects."

20 John Bongaarts, "The causes of educational differences in fertility in sub-Saharan Africa."

19 Ashish Bajracharya and Sajeda Amin, "Poverty, marriage timing, and transitions to adulthood in Nepal: A longitudinal analysis using the Nepal Living Standards Survey." 